\title{
VALIDITY AND RELIABILITY OF THE PORTUGUESE VERSION OF THE CONFUSION ASSESSMENT METHOD (CAM) FOR THE DETECTION OF DELIRIUM IN THE ELDERLY
}

\author{
Renato Moraes Alves Fabbri', Marcos Aurélio Moreira², \\ Regiane Garrido3, Oswaldo Pereira Almeida ${ }^{4}$
}

\begin{abstract}
This study has tested the validity and reliability of the Portuguese version of the Confusion Assessment Method (CAM), a diagnostic assessment instrument for delirium developed by Inouye et al. (1990). The sample was formed by 100 patients with 60 and more years of age, admitted at the emergency service of Santa Casa de São Paulo, in the time periods between July and August, 1996, November and December, 1996 and February and March, 1997. The sensibility was $94.1 \%$ and specificity $96.4 \%$. The assessors reliability in a sample of the 24 patients resulted in a kappa $=0.70$. We have concluded that CAM is an adequate instrument to assess the presence of delirium, reliable to assess elderly patients at the emergency services.
\end{abstract}

KEY WORDS: delirium, elderly, emergency service, validity, CAM.

\begin{abstract}
Validação e confiabilidade da versão em língua portuguesa do confusion assessment method (CAM) para a detecção de delirium no idoso.

RESUMO - O presente estudo testou a validade e confiabilidade da versão em língua portuguesa do Confusion Assessment Method (CAM), instrumento de avaliação diagnóstica de delirium desenvolvido por Inouye e col. (1990). A amostra foi composta de 100 pacientes com idade igual ou superior a 60 anos atendidos no serviço de urgência da Santa Casa de São Paulo nos períodos de julho a agosto de 1996, novembro a dezembro de 1996 e fevereiro a março de 1997 . Os resultados apontaram sensibilidade de $94,1 \%$ e especificidade de $96,4 \%$. Confiabilidade entre avaliadores em subgrupos de 24 pacientes produziu kappa $=0,70$. Concluimos que o CAM é um instrumento que afere a presença de delirium de forma adequada e que pode ser utilizado de forma confiável na avaliação de pacientes idosos atendidos em serviços de urgência.
\end{abstract}

PALAVRAS-CHAVE: delirium, idoso, serviço de urgência, validação, CAM.

Presently, delirium is defined as an organic brain syndrome without specific etiology, characterized by the simultaneous presence of disturbances related to consciousness and attention, perception, thinking, memory, psychomotor behavior, emotions and sleep-wake cycle ${ }^{1}$. Prevalence studies indicate that delirium is present in $10-24 \%$ of adults admitted to hospital and that another $32 \%$ will develop the disorder as inpatients ${ }^{2,3}$. Typical symptoms of delirium include reduced ability to focus and maintain attention, memory deficits, disorientation, language difficulties, illusions, hallucinations, and many other behavioral abnormalities. Infection, cardiovascular diseases, metabolic disturbances, and drug use or withdrawal are the most frequent causes of de- lirium ${ }^{4,5}$. Only $33-64 \%$ of the patients with delirium are correctly identified by practicing physician ${ }^{6-10}$. This is a major source of concern, as delirium is associated with increased morbidity and mortality ${ }^{11-16}$.

A number of scales and semi-structured interviews have been designed to assist the clinician with the assessment and diagnosis of delirium ${ }^{17}$. One such instrument, the "Confusion Assessment Method" (CAM), has gained wide acceptance among medical practitioners. The scale shows good sensitivity (94$100 \%$ ) and specificity (90-95\%) when compared to the diagnosis of delirium according to the Diagnostic and Statistical Manual Disorders (DSM) III-R criteria $^{18}$ and inter-observer reliability rates are high $(\mathrm{kappa}=0.81 \text { to } 1.00)^{19}$.

\footnotetext{
${ }^{1}$ Division of Geriatric Medicine, Department of Medicine, Santa Casa Medical School (São Paulo, Brazil); ${ }^{2}$ Division of Neurology, Department of Medicine, Santa Casa Medical School; ${ }^{3}$ Department of Psychiatry, Santa Casa Medical School; ${ }^{4}$ UWA Department of Psychiatry, Queen Elisabeth II Medical Centre, Nedlands, Perth, WA 6009, Australia.
}

Received 14 July 2000, received in final form 26 October 2000. Accepted 3 November 2000. 
We designed the present study to investigate the reliability of the Brazilian version of the CAM as well as validity according to DSM-IV criteria for the diagnosis of delirium ${ }^{20}$.

\section{METHOD}

One hundred subjects were selected among the older adults (age 60 years or over) assessed during the Winter and Spring of 1996, and Summer of 1997 at the Emergency Room of a large teaching hospital in the city of São Paulo, Brazil, the "Hospital Santa Casa de São Paulo". Patients in mutism or those who scored 11 or more in the "Glasgow scale" 20 were excluded from the study.

All subjects were assessed with the Brazilian version of the $\mathrm{CAM}^{19}$. The scale was translated from the original version into Portuguese and then back into English by an independent translator with the aim of ensuring the maintenance of the meaning of all items. Briefly, the CAM consists of 9 sections assessing rate of onset, attention, thinking, level of consciousness, orientation, memory, sensory perception, psychomotor activity, and sleep-wake cycle (Table 1). The diagnosis of delirium by the CAM requires the presence of acute onset/fluctuating course and inattention, and disorganized thinking or altered level of consciousness.

All subjects were assessed by a geriatrician with the CAM within 24 hours after admission to the Emergency Room. An independent psychiatrist interviewed patients using the DSM-IV criteria for the diagnosis of mental disorders (including delirium). The interval between these two assessments was never longer than 2 hours. A subset of 24 subjects independently rated with the CAM by geriatrician and a clinician during the same interview. These rates were used to investigate the inter-observer reliability of the CAM.

Data analysis. The data were analyzed using the Statistical Package for the Social Sciences (SPSS 6.0 for Windows). Likelihood ratio analysis of contingency tables was used in the investigation of categorical data, the statistical result being distributed as chi-squared ${ }^{3}$. The relative risk of certain events was estimated by the "odds ratio" statistic. Agreement between raters and between CAM/ DSM-IV diagnosis of delirium was calculated with the kappa statistic. Student's t-test (t) was used to compare the means of continuos (in practical terms) non-skewed data such as age (the degrees of freedom for the t-tests equal the total number of subjects minus 2). Ninety-five percent confidence intervals $(\mathrm{Cl})$ were calculated for the means, difference between means (Cid), and odds ratio (Ciodds). In the case of non-parametric data the Cid refers to difference between means, and is presented only as an estimate of the difference between groups.

\section{RESULTS}

A total of 1044 patients or above were assessed at the Emergency Room during the study period.
Three hundred and ninety-six $(37,9 \%)$ were aged 60 years or older, although only 100 of them were included in the study. Reasons for exclusion include: (A) the clinical state of the patient prevented assessment $(n=61),(B)$ the time length between assessment with the CAM and the mental state evaluation according to the DSM-IV was longer than 2 hours $(n=41),(C)$ the patient was discharged from the Emergency Room in less 24 hours $(n=194)$.

The mean age of the 100 subjects included in the study was $73.80(\mathrm{Cl}=72.12$ to 75.48$)$. Fifty-two were male, 46 were married, and $84 \%$ were of European descent. Third-two subjects were unable to read or write fluently, and only 15 of the elderly had more than 8 years of formal education.

A convenience sub-sample of 24 patients was selected for the inter-observer reliability study of the CAM. There was no age (mean age $=74.50 / 73.37$, $\mathrm{t}=0.57, \mathrm{p}=0.570$ ) nor gender (percentage of males $=58.3 / 50.0 \%),(20.51, p=0.0476)$ difference between subjects selected/not selected for the study. The two raters agreed on 22/24 ratings, with 3 of the patients receiving the diagnosis of delirium (kappa $=0.70$ ).

Seventeen and 19 subjects fulfilled criteria for delirium according to DSM-IV and the CAM respectively. Sixteen were classified as cases of delirium by both the DSM-IV and the CAM (kappa=0.86). The CAM showed good specificity $(96.4 \%)$, sensitivity $(94.1 \%)$, positive predictive value $(84.2 \%)$, and negative predictive value $(98.7 \%)$ for the diagnosis of delirium according to DSM-IV criteria. Table displays specificity, sensitivity, and positive and negative values for the diagnosis of delirium all CAM items.

\section{DISCUSSION}

Delirium is the result of an organic insult to the brain that hinders its appropriate functioning. In spite of its organic basis, the diagnosis of delirium is totally based on the clinical presentation of the patient, which can be subtle and difficult to identify. The use of International Statistical Classification of Diseases and Related Health Problems $-10^{\text {a }}$ rev (ICD$10)^{22}$ or DSM-IV ${ }^{20}$ criteria has contributed to improve the awareness of clinicians for the diagnosis of delirium in clinical settings, although a large proportion of cases remain undiagnosed ${ }^{6-8}$. The systematic use of delirium scales increase the detection rate of cases.

A number of scales have been devised for that purpose. In 1973 Lowy and colleagues introduced the "Delirium Scale" (D-Scale), which included 53 
Table 1. Portuguese version of the confusion assessment method - CAM (Inouye et al. $\left.{ }^{19}, 1990\right)$.

1) Início agudo

Há evidência de uma mudança aguda do estado mental de base do paciente?

2) Distúrbio da atenção*

2.A) O paciente teve dificuldade em focalizar sua atenção, por exemplo, distraiu-se facilmente ou teve dificuldade em acompanhar o que estava sendo dito?

- Ausente em todo o momento da entrevista

- Presente em algum momento da entrevista, porém de forma leve

- Presente em algum momento da entrevista, de forma marcante

- Incerto

2.B) Se presente ou anormal, este comportamento variou durante a entrevista, isto é, tendeu a surgir e desaparecer ou aumentar e diminuir de gravidade?

- Sim

- Não

- Incerto

- Não aplicável

2.C) Se presente ou anormal, descreva o comportamento:

3) Pensamento desorganizado

O pensamento do paciente era desorganizado ou incoerente, com a conversação dispersiva ou irrelevante, fluxo de idéias pouco claro ou ilógico, ou mudança imprevisível de assunto ?

4) Alteração do nível de consciência

Em geral, como você classificaria o nível de consciência do paciente ?

- Alerta (normal)

- Vigilante (hiperalerta, hipersesível a estímulos ambientais, assustando-se facilmente)

- Letárgico (sonolento, facilmente acordável)

- Estupor (dificuldade para despertar)

- Coma

- Incerto

5) Desorientação

O paciente ficou desorientado durante a entrevista, por exemplo, pensando que estava em outro lugar que não o hospital, que estava no leito errado, ou tendo noção errada da hora do dia ?

6) Distúrbio (prejuízo) da memória

O paciente apresentou problemas de memória durante a entrevista, tais como incapacidade de se lembrar de eventos do hospital, ou dificuldade para se lembar de instruções ?

7) Distúrbios de percepção

O paciente apresentou sinais de distúrbios de percepção, como por exemplo alucinações, ilusões ou interpretações errôneas (pensando que algum objeto fixo se movimentava)?

8) Agitação psicomotora

Parte 1 - Durante a entrevista, o paciente apresentou aumento anormal da atividade motora, tais como agitação, beliscar de cobertas, tamborilar com os dedos ou mudança súbita e frequente de posição ?

Retardo psicomotor

Parte 2 - Durante a entrevista, o paciente apresentou diminuição anormal da atividade motora, como letargia, olhar fixo no vazio, permanência na mesma posição por longo tempo, ou lentidão exagerada de movimentos?

9) Alteração do ciclo sono-vigília

O paciente apresentou sinais de alteração do ciclo sono-vigília, como sonolência diurna excessiva e insônia noturna ? 
Table 2. Sensitivity, specitivity, positive predictive value (PPV) and negative predictive value (NPV) of CAM individual items

\begin{tabular}{lcccc}
\hline Clinical feature & Sensitivity & Specificity & PPV & NPV \\
\hline Acute onset & 94.1 & 93.9 & 76.1 & 98.7 \\
Inattention & 94.1 & 87.9 & 61.5 & 98.6 \\
Disorganized thinking & 76.4 & 98.7 & 92.8 & 95.3 \\
Altered level of consciousness & 88.2 & 87.9 & 60.0 & 97.3 \\
Disorientation & 70.5 & 87.9 & 54.5 & 93.5 \\
Memory impairment & 100 & 54.2 & 30.9 & 100 \\
Perceptual impairment & 11.7 & 100 & 100 & 84.6 \\
Psychomotor agitation & 17.6 & 98.7 & 75.0 & 85.4 \\
Psychomotor retardation & 70.5 & 91.5 & 63.5 & 93.8 \\
Altered sleep-wake cycle & 64.7 & 92.7 & 64.7 & 92.7 \\
Total CAM schedule & 94.1 & 96.3 & 84.2 & 98.8 \\
\hline
\end{tabular}

items assessing cognitive functioning ${ }^{23}$. The D-Scale has the merit of having been one of the first attempts to make a more systematic evaluation of these patients, although its rather complex design limited its use in clinical practice ${ }^{17,24}$. The "Mini-Mental State Examination" (MMSE) ${ }^{25}$ has also been occasionally used as a screening test for delirium, even though low rates are not necessarily indicative of delirium ${ }^{24,26-}$ ${ }^{29}$. Others have been specially designed for the evaluation of patients by non-medics. Examples are the NEECHAM Confusion Scale, Confusion Rating Scale, Clinical Assessment Confusion, Nursing Delirium Rating Scale and the Delirium Symptom Interview ${ }^{15,24}$. There also instruments that were designed to assess the severity of the clinical features of patients with delirium: Delirium Rating Scale, Memorial Delirium Assessment Scale, and Confusion State Evaluation $^{17,30,31}$.

The CAM was developed with the aim of helping non-psychiatrists identifying cases of delirium. The scale has been used widely, particularly because it is reliable and has a friendly format ${ }^{32-40}$. The present study aimed to validate the Brazilian version of the CAM according DSM_IV criteria ${ }^{20}$. The Scale showed high levels of sensitivity (94.1\%) and specificity (96.4\%). It also showed high positive (84.2\%) and negative $(98.8 \%)$ predictive values, which suggests that very few cases of delirium are not identified if the scale is used systematically. Only 4 of 100 subjects evaluated with the CAM were misdiagnosed. Three cases were incorrectly classified as delirium, with 1 of the patients actually suffering from dementia. Others ${ }^{28,29}$ had already suggested that the differential diagnosis of delirium and dementia can be difficult, particularly because they share many common clinical features. In addition, patients with dementia are more vulnerable to the development of delirium, so that both disorders can coexist in the same patient at the same time ${ }^{41}$. The CAM can also be used reliably by different ratters (kappa $=0.70)$, and we expect that higher levels of agreement might be achieved with appropriate training programs.

In summary, we showed that the CAM is a valid and reliable instrument for the assessment of delirium among older adults. We anticipate that its systematic use in high risk clinical settings, such as emergency rooms, will improve detection rates and contribute to decrease the morbidity and mortality associated with the clinical diagnosis of delirium.

\section{REFERENCES}

1. OMS, Organização Mundial de Saúde. Classificação esatatística internacional de doenças e problemas relacionados à saúde. $10^{\mathrm{a}}$ revisão. São Paulo: EDUSP, 1994.

2. Francis J. Delirium in older patients. J Am Geriatr Soc 1994; 40: 829-838.

3. O'Keefe ST, Lavan JN. The prognostic significance of delirium in older hospital patients. J Am Geriatr Soc 1997;45:174-178.

4. Lipowski ZJ. Delirium: acute confusional states. Oxford: Oxford Univ Press,1990:3-37.

5. Maciel AC. Delirium (confusão mental aguda) no idoso. Gerontologia 1994;2:97-102.

6. Boland RJ, Diaz S, Lamdam R, Ramchandadani D, McCartney JR. Overdiagnosis of depression in the general hospital. Gen Hosp Psychiatry 1996;18:28-35.

7. Farrel KR, Ganzini L. Misdiagnosing delirium as depression in medically ill elderly patients. Arch Intern Med 1995;155:2459-2464.

8. Inouye SK. The dilema of delirium: clinical and research controversies regarding diagnosis and evaluation of delirium in hospitalized elderly medical patients. Am J Med 1994;97:278-288.

9. Pompei P, Foreman M, Cassel CK, et al. Detecting delirium among hospitalized older patients. Arch Intern Med 1995;155:301-307. 
10. Rockhood K, Cosway S, Stolee P, et al. Increasing the recognition of delirium in elderly patients. J Am Geriatr Soc 1994;42:252-256.

11. Chan D, Brennan N. Delirium: Making the diagnosis, improving the prognosis. Geriatrics 1999;54:28-42.

12. Cole MG, Primeau FJ. Prognosis of delirium in elderly hospital patients. Can Med Assoc J 1993;149:41-46.

13. Francis J, Kapoor WN. Prognosis after hospital discharge of older medical with delirium. J Am Geriatr Soc 1992;40:601-606.

14. Levkoff SE, Evans DA, Liptzin B, et al. Delirium: the occurrence and persistence of symptoms among elderly hospitalized patients. Arch Intern Med 1992;152:334-340.

15. Trzepacz PT. Delirium: advances in diagnosis, pathophysiology, and treatment. Psychiat Clin N Am 1996;19:429-448.

16. van Hemert AM, van der Mast RC, Hengeveld MW, et al. Excess mortality in general hospital patients with delirium: a year follow-up study of 519 patients seen in psychiatric consultation. J Psychosom Res 1994;34:339-346.

17. Trzepacz PT. A review of delirium assessment instruments. Gen Hosp Psychiatry 1994;16:397-405.

18. Diagnostic and statistical manual of mental disorders. 3.Ed, Revised.Washington, DC: American Psychiatric Association, 1987.

19. Inouye SK, van Dick $\mathrm{CH}$, Alessi CA, et al. Clarifying confusion: the confusional assessment method: a new method for detection of delirium. Ann Intern Med 1990;113:941-948.

20. Diagnostic and statistical manual of mental disorders. 4.Ed. Washington, DC: American Psychiatric Association, 1994.

21. Teasdale G, Jennet B. Assessment of coma and impaired consciousness: a practical scale. Lancet 1974;2:81-83.

22. WHO. World Health Organization. ICD 10. Geneva. WHO, 1993.

23. Lowy FH, Engelsmann F, Lipowski ZJ. Study of cognitive functioning in a medical population. Comprehensive Psychiatry 1973;14:331-338.

24. Levkoff SE, Liptzin B, Cleary P et al. Review of research instruments and techniques used to detect delirium. Int Psychogeriatry 1991;3:253-271.

25. Folstein MF, Folstein SE, McHugh PR. Mini-mental state: a practical method for grading the cognitive state of patients for the clinician. J Psychiat Res 1975;12:189-198.

26. Anthony JC, Le Resche L, Niaz U et al. Limits of the "Mini-Mental State" as a screening test for dementia and delirium among hospital patients. Psychol Med 1982;12:397-408.
27. Erkinjuntti T, Sulkava R, Wikström, et al. Short portable among status questionnaire as a screening test for dementia and delirium among the elderly. J Am Geriatr Soc 1987;35:412-416.

28. Jacobson AS. Delirium in the elderly. Psychiatr Clin N Am 1997;20:91-109.

29. Rummans TA, Evans JM, Krahn LE, et al. Delirium in elderly patients: evaluation and management. Mayo Clin Proc 1995;70:989-998.

30. Rockhood K, Goodman J, Flynn M, et al. Cross-validation of the delirium rating scale in older patients. J Am Geriatr Soc 1996;44:839-842.

31. Robertsson B, Karlsson I, Styrud E, et al. Confusional state evaluation: an instrument for measuring severity of delirium in the elderly. Br J Psychiatry 1997; 170:565-570.

32. Flacker JM, Cummings V, Mach JR et al. The association of serum anticholinergic activity with delirium in elderly medical patients. Am J Geriatr Psychiatry 1998;6:31-41.

33. Inouye SK, Charpentier PA. Precipitating factors for delirium in hospitalized elderly persons. JAMA 1996;275:852-857.

34. Lynch EP, Lazor MA, Gellis JE, et al. The impact of postoperative pain on the development of postoperative delirium. Anesth Analg 1998;86:781-785.

35. Marcantonio ER, Goldman L, Orav EJ, et al. The association of intraoperative factors with the development of postoperative delirium. Am J Med 1998;105:380-384.

36. MacCusker J, Cole M, Bellevance F et al. Reliability and vality of a new measure of severity of delirium. Int Psychogeriatry 1998;10:421-433.

37. Naughton BJ, Moran MB, Kadah H, et al. Delirium and other cognitive impairment in older adults in an emergency department. Ann Emerg Med 1995;25:751-755.

38. Pompei P, Foreman M, Cassel CK, et al. Detecting delirium among hospitalized older patients. Arch Intern Med 1995;155:301-307.

39. Sanders AB. Recognition of cognitive problems in older adults by emergency medicine personnel. Ann Emerg Med 1995;25:831-833.

40. Zou Y, Cole MG, Primeau FJ et al. Detection and diagnosis in the elderly: psychiatrist diagnosis, confusion assessment method, or consensus diagnosis? Int Psychogeriatry 1998;10:303-308.

41. Lipowski, ZJ. Delirium in the elderly patient. N Eng J Med 1989;320:578-583 